\title{
Impact of Climat Change and Human Activity on Water Quality of Babar Dam, Algeria
}

\author{
Aissam G* and Abderrahmane B \\ Laboratory of Applied Research in Hydraulics, University of Batna, Algeria
}

Submission: February 13, 2018; Published: June 26, 2018

*Corresponding author: Aissam G, Laboratory of Applied Research in Hydraulics, University of Batna 2, 05 078. Fesdis-Batna, Algeria,

Email: gaagai_aissam@hotmail.fr

\begin{abstract}
The quality of surface water has in recent years, a deterioration largely due to a climate change. The objective of this study was to evaluate the impact of a long drought and human activities on water quality in a dam of eastern Algeria, the Babar. To achieve this, a study of the composition of the waters of the dam using the method of trends was performed. The results show that the water has a calcium-magnesium-sulfated facies. They show that most parameters follow negative trends, with the exception of $\mathrm{K}(41.56 \%), \mathrm{NO}_{2}(5 \%)$ and $\mathrm{NO}_{3}(35.62 \%)$. The use of potash fertilizers and the discharge spills of village waste directly into the dam basin without any prior treatment leads to an increase in K. The increase in $\mathrm{NO}_{3}$ is mainly due to fertilizer and nitrification of ammonium (-61\%), which was accompanied by a decrease in the levels of dissolved oxygen $(-7.5 \%)$. The decrease in the orthophosphate content $(-80 \%)$ is due to its low mobility on the one hand, and to the removal of phosphorus on the other hand by the processes of mechanical erosion from the adsorption of the latter by the soil colloids. This approach has shown that drought and anthropogenic activity have a negative impact on the quality of surface water.
\end{abstract}

Keywords: Dam; Trend method; Anthropic; Nitrification; Algeria

Abbreviations: ANRH: National Water Resources Agency; DCO: Chemical Oxygen Demand; MES: Suspended Matter; CE: Electrical Conductivity

\section{Introduction}

Intheface of climate changethathas hit the world in recentyears, The quality of surface water has also been a major deterioration due to agricultural, urban and industrial development. Many water quality variables are subject to large fluctuations in space and time and understanding these fluctuations in the environment can be a difficult task [1]. The factors of natural influence may be due to changes in precipitation, erosion, alteration of the materials of the earth's crust or else they are due to anthropogenic action such as urban, industrial and agricultural activities as well as excessive exploitation of water resources [2]. These factors work together to create a type of water whose chemical composition varies in space and time [3]. In addition, in river monitoring, it is often necessary to determine whether a variable should be attributed to natural or anthropogenic causes [4]. According to HamzaouiAzaza et al. [5], knowledge of the geochemical evolution of water quality could lead to effective management of water resources. Thus, the quality of the water is just as important as the quantity. Several studies around the world [6-17] and in Algeria [18-30] are reported on the effects of agricultural, industrial and urban effluents on the quality of surface water. Wadi El Arab controlled by Babar Dam, was built for the supply of potable water and the supply of industrial water and irrigation. The water stored in the basin of this dam is deteriorating in quality due to different types of pollution, in addition to the natural processes of erosion and leaching of various toxic elements. A physicochemical analysis program which has made it possible to build a data bank, which should be analyzed, and to detect significant trends. This study therefore presents details of the fluctuations in the chemical composition of the water of the Babar dam between January 2013 and March 2016. This work makes it possible to understand the hydro chemical behavior of the surface waters of the dam. The trend analysis applied here is determined by linear regression, using the least squares method following the time series of the water quality parameters, it is a simple and easy method to implement.

\section{Materials and Methods}

\section{Study zone}

The study area is located in the south-east of Algeria, in the eastern confines of the Saharan Atlas and precisely in the mountain range of Djebel Djehfa belonging to the Nememcha Mountains. Most of the inhabitants (more than 20,000 inhabitants) are concentrated in the city of Babar. The surface of the subwatershed is $567 \mathrm{~km}^{2}$, the dam of Babar has a capacity of $42 \mathrm{Mm}^{3}$, built to retain the waters of Oued Tamagra in the West and Oued El Htiba in the East. The Babar Dam is located at $35^{\circ} 10^{\prime} 10^{\prime \prime} \mathrm{N}$ and $7^{\circ} 01^{\prime} 41^{\prime \prime} \mathrm{E}$ and 


\section{Civil Engineering Research Journal}

the town of Babar is located at $35^{\circ} 10^{\prime} 4^{\prime \prime} \mathrm{N}$ and $7^{\circ} 06^{\prime} 7^{\prime \prime} \mathrm{E}$ (Figure 1). An increase in the population and inadequate domestic sewer systems have potential to influence the water quality of the dam. The Wadi El Arab provides water for nearby cities and irrigates thousands of hectares of farmland. The increase in water demand at the development stage, including agriculture, could lead to a bleak future for the water quality of the dam.

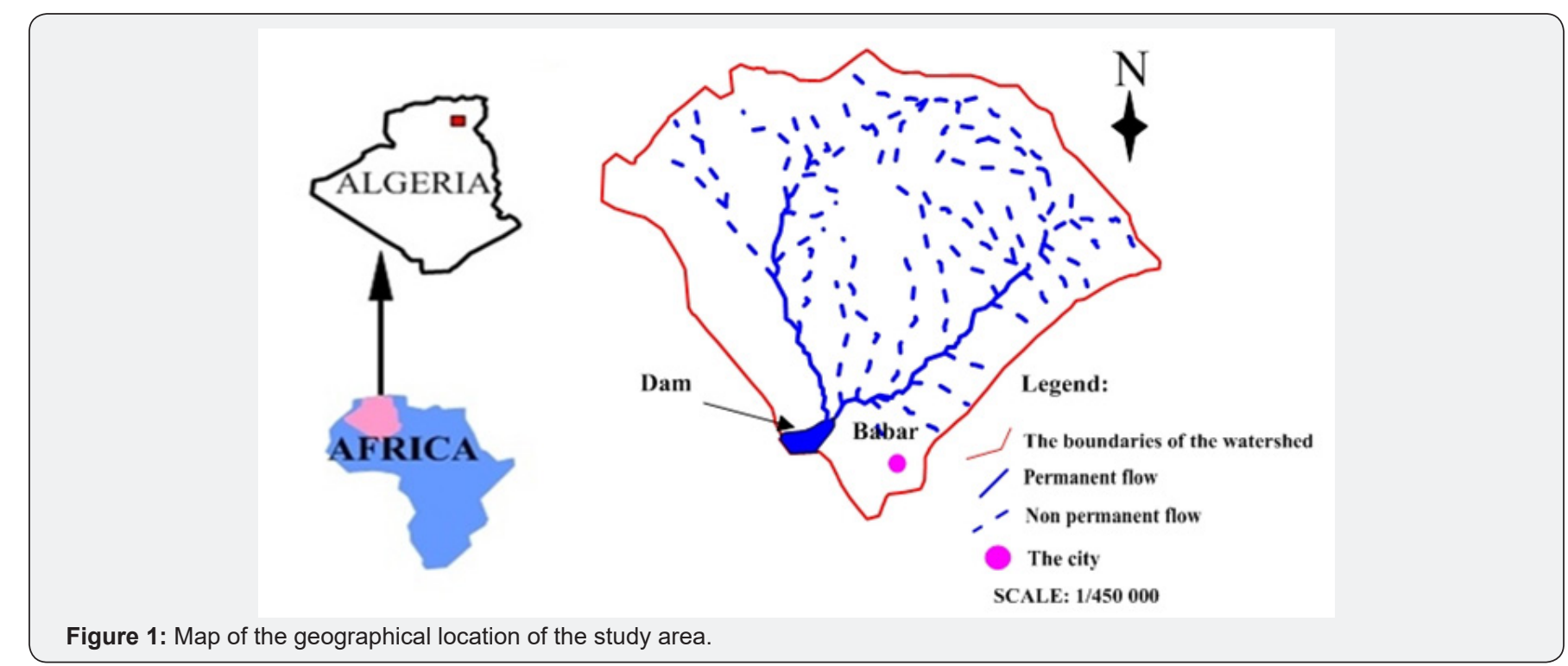

\section{Analytical methods}

The trend method was applied to the physicochemical data of the surface waters of the Babar dam during the 39-month period from January 2013 to March 2016. This method allows to acquire representative data on the spatial and temporal variability of the surface water quality of the Babar Dam on Oued El Arab. For this, we used the data of physico-chemical analyses, carried out by the National Water Resources Agency (ANRH) of Constantine. The measured parameters are determined by the ANRH such as: PH, suspended matter (MES), electrical conductivity of water (CE), surface water temperature of Babar Dam reservoir (T), turbidity (crude), organic matter (MO), calcium $\left(\mathrm{Ca}^{2+}\right)$, magnesium $\left(\mathrm{Mg}^{2+}\right)$, sodium $\left(\mathrm{Na}^{+}\right)$, potassium $\left(\mathrm{K}^{+}\right)$, chlorides $(\mathrm{Cl})$, sulphate $\left(\mathrm{SO}_{4}{ }^{2-}\right)$, bicarbonate $\left(\mathrm{HCO}_{3}^{-}\right)$, nitrate $\left(\mathrm{NO}_{3}^{-}\right)$, nitrite $\left(\mathrm{NO}_{2}^{-}\right)$, ammonium $\left(\mathrm{NH}_{4}{ }^{+}\right)$, Orthophosphate $\left(\mathrm{PO}_{4}{ }^{3-}\right)$, biological oxygen demand in Five days $\left(\mathrm{DBO}_{5}\right)$, chemical oxygen demand (DCO), dissolved oxygen $\left(\mathrm{O}_{2}\right.$ dis), variation of the water reserve at the deduction level (VR). This technique was applied to the instantaneous monthly physicochemical data of the Babar Dam, during the period from January 2013 to March 2016 using the Excel 2007. And which constitute a chronological series of 39 analyses and 21 variables (Table 1).

Table 1: Statistical characteristics of chemical data from Babar Dam in the long term.

\begin{tabular}{|c|c|c|c|c|c|c|c|c|c|}
\hline Paramètres & $y=a t+b$ & T \% & Min. & Max. & avg & $\sigma$ & $\mathrm{CV}$ & $\mathbf{R}$ & NA \\
\hline $\operatorname{Vr}(\mathrm{Mm} 3)$ & $\mathrm{Vr}=0.001 \mathrm{t}-20.06$ & 3.41 & 30.222 & 38.005 & 35.29 & 35.12 & 0.276 & / & / \\
\hline $\mathrm{T}^{\circ} \mathrm{C}$ & $\mathrm{T}=0.000 .1 \mathrm{t}+1.377$ & 2.69 & 7 & 32 & 16.9 & 6.88 & 0 & / & 25 \\
\hline MES mg/l & $C=-0.344 t+29.46$ & -42.81 & 8 & 44 & 22.51 & 10.81 & 0.34 & -0.35 & 25 \\
\hline $\mathrm{pH}$ & $\mathrm{pH}=-9 \mathrm{E}-0.5 \mathrm{t}+11.4$ & -1.24 & 7.17 & 8.08 & 7.78 & 0.175 & 0.17 & -0.001 & $6.5-8.5$ \\
\hline $\mathrm{CE}(\mu \mathrm{s} / \mathrm{cm})$ & $C=-0.202 t+9704$ & -17.54 & 1070 & 1400 & 1222.05 & 86.82 & 0.81 & -0.81 & 2800 \\
\hline $\begin{array}{c}02 \text { disso } \\
\mathrm{mg} / \mathrm{l}\end{array}$ & $C=-0.0001 t+34.5$ & -7.5 & 5.7 & 13.6 & 9.63 & 9.61 & 0.12 & 0.06 & 30 \\
\hline MO mg/l & $C=-0.001 t+66.92$ & -24.52 & 3.5 & 9 & 6.28 & 6.29 & 0.37 & -0.21 & / \\
\hline $\begin{array}{l}\text { DCO mg/l } \\
\text { d' O2 }\end{array}$ & $C=-0.003 t+199$ & -11.84 & 18 & 48 & 35.64 & 35.66 & 0.184 & -0.24 & 30 \\
\hline $\begin{array}{c}\text { DBO5 mg/l } \\
\text { d' } 02\end{array}$ & $C=-0.001 t+72.49$ & -38.33 & 0 & 6 & 2 & 2.08 & 0.22 & -0.41 & 7 \\
\hline PO4 mg/l & $C=-4 E-0.5 t+1.765$ & -80 & 0 & 0.13 & 0.036 & 0.036 & 0.41 & -0.2 & 0.5 \\
\hline $\mathrm{NH} 4 \mathrm{mg} / \mathrm{l}$ & $C=-7 E-0.5 t+2.903$ & -61.91 & 0 & 0.43 & 0.095 & 0.035 & 0.28 & -0.11 & $0.05-0.5$ \\
\hline NO2 mg/l & $C=1 E-06 t-0.015$ & 5 & 0 & 0.23 & 0.041 & 0.041 & 0 & 0.21 & 0.1 \\
\hline NO3 mg/l & $C=0.0001 t-14.79$ & 35.62 & 0 & 9 & 1.74 & 1.8 & 0.071 & -0.04 & 50 \\
\hline $\mathrm{HCO} 3 \mathrm{mg} / \mathrm{l}$ & $C=-0.024 t+1156$ & -18.95 & 79.3 & 384.3 & 137.47 & 137.9 & 0.184 & 0.13 & I \\
\hline
\end{tabular}




\section{Civil Engineering Research Journal}

\begin{tabular}{|c|c|c|c|c|c|c|c|c|c|}
\hline $\mathrm{SO} 4 \mathrm{mg} / \mathrm{l}$ & $\mathrm{C}=-0.05 \mathrm{t}+2511$ & -13.1 & 260 & 502 & 407.05 & 407.51 & 0.332 & -0.55 & 400 \\
\hline $\mathrm{Cl} \mathrm{mg} / \mathrm{l}$ & $\mathrm{C}=-0.028 \mathrm{t}+1254$ & -34.21 & 30 & 205 & 78.33 & 78.58 & 0.373 & -0.07 & 500 \\
\hline $\mathrm{Ca} \mathrm{mg} / \mathrm{l}$ & $\mathrm{C}=-0.004 \mathrm{t}+334.6$ & -4.29 & 81.06 & 169.24 & 137.17 & 138.05 & 0.084 & -0.18 & 200 \\
\hline $\mathrm{Mg} \mathrm{mg} / \mathrm{l}$ & $\mathrm{C}=-0.017 \mathrm{t}+782.8$ & -44.37 & 9.84 & 51.89 & 36.06 & 35.51 & 0.534 & -0.35 & 150 \\
\hline $\mathrm{Na} \mathrm{mg} / \mathrm{l}$ & $\mathrm{C}=-0.014 \mathrm{t}+674.5$ & -22.04 & 19 & 134 & 66.38 & 67.01 & 0.263 & -0.08 & 200 \\
\hline $\mathrm{K} \mathrm{mg} / \mathrm{l}$ & $\mathrm{C}=0.001 \mathrm{t}-44.29$ & 41.56 & 1 & 5 & 3.86 & 3.87 & 0.437 & 0.51 & 12 \\
\hline
\end{tabular}

In this study, we will effectively present trends in physicochemical parameters using a linear regression method. It is a model based on linear least squares equations. Whatever the case, three trend classes have been defined: ' + ' if a positive trend is detected; ' 0 ' if no significant trend is detected; and '-' if a negative trend is observed. The use of this technique thus makes it possible to highlight the possible effects of anthropogenic pollution in the long term. [6]. This goal is also achieved using the moving average that allows a smoothing that eliminates seasonality and minimizes background noise [26]. The method consists in calculating the moving averages by choosing as length, the period of seasonal variations, so as to make them disappear.

\section{Results and Discussion}

\section{Characterization of dam water}

An examination of the standard deviation and coefficient of variation shows that (Table 1):

- Water, $\mathrm{pH}, \mathrm{DCO}, \mathrm{NO}_{2}, \mathrm{NO}_{3}, \mathrm{HCO}_{3}, \mathrm{Ca}$ and $\mathrm{O}_{2}$ dis have a small variation $(<20 \%)$;

- $\quad$ MES, $\mathrm{MO}, \mathrm{DBO}_{5}, \mathrm{NH}_{4}, \mathrm{SO}_{4}, \mathrm{Cl}$ and $\mathrm{Na}$ show a variation around the average oscillated between 20 and $40 \%$;

- $\quad$ The rest of the elements (Turbidity, $\mathrm{CE}, \mathrm{PO}_{4}, \mathrm{Mg}$ and $\mathrm{K}$ ) show a strong variation around the average ( $>40 \%)$.
These strong variations resulting from the effluents and the leaching of the grounds following torrential precipitations, badly distributed especially in the time.

The examination of these data also shows that the concentrations of the various elements are below Algerian standards with the exception of:

- $\mathrm{SO}_{4}$ where $66.6 \%$ of the data exceed the standard during the study period;

- $\quad \mathrm{NO}_{2}$ where $5.12 \%$ of the data exceed the standard.

- Turbidity where $36.46 \%$ of the data exceed the standard. With maximum values recorded during the year 2013.

- $\quad$ MES where $35.89 \%$ of the data exceed the standard. It has a similar evolution as turbidity.

The Piper diagram for these waters shows that the samples have a sulfated-calcium to magnesium facies (Figure 2). The first of the things we noticed between the first campaign (October 2007 to April 2008) and the second campaign (January 2013 to March 2016), no changes were made to the chemical characteristics of the dam's waters. According to Faurie [31] and Durand [32], calcium can come from inputs of nitrogen fertilizers that participate in the dissolution of carbonates according to the equations 1 and 2 [33].

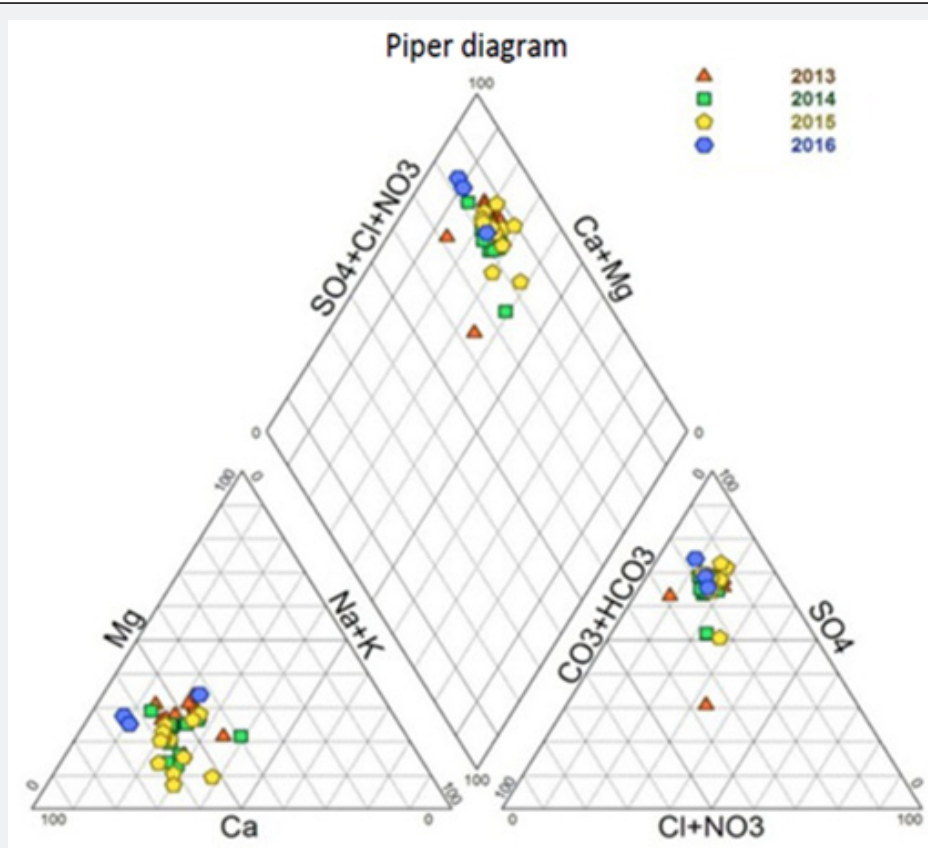

Figure 2: Piper diagram applied to the waters of the Babar dam (January 2013 to March 2016). 


\section{Civil Engineering Research Journal}

$\mathrm{NH}_{4}^{+}+2 \mathrm{O}_{2} \leftrightarrow \mathrm{NO}_{3}^{-}+2 \mathrm{H}^{+}+\mathrm{H}_{2} \mathrm{O}$

$\mathrm{CaCO}_{3}+\mathrm{H}^{+} \leftrightarrow \mathrm{Ca}_{2}^{+}+\mathrm{HCO}_{3}{ }^{-}$

The global equation (3) can be written in the following way:

$\mathrm{NH}_{4}{ }^{+}+2 \mathrm{O}_{2}+2 \mathrm{CaCO}_{3} \leftrightarrow \mathrm{NO}_{3}{ }^{-}+2 \mathrm{Ca}^{2+}+2 \mathrm{HCO}_{3}{ }^{-}+\mathrm{H}_{2} \mathrm{O}$

According to the relationship (3), the molar ratio between $\mathrm{Ca}^{2+}$ and $\mathrm{HCO}_{3}{ }^{-}$when nitrification is 1 , Whereas, according to equation (4), the molar ratio $\mathrm{Ca}^{2+} / \mathrm{HCO}_{3}^{-}$is equal to 2 , when the dissolution of Carbonates is in association with atmospheric $\mathrm{CO}_{2}$.

$$
\mathrm{CaCO}_{3}+\mathrm{H}_{2} \mathrm{O}+\mathrm{CO}_{2} \leftrightarrow 2 \mathrm{HCO}_{3}^{-}+\mathrm{Ca}^{2+}(4)
$$

The surface waters of the Babar dam have a molar ratio $\mathrm{Ca}^{2+} /$ $\mathrm{HCO}_{3}{ }_{3}^{-}$between 1 and 1.5 in $72 \%$ of cases and an $\mathrm{Mg}^{2+} / \mathrm{HCO}_{3}^{-}$ratio are $<1$ in $100 \%$ of cases. This corresponds to the proportion given by equation (3). So the increase of $\mathrm{Ca}^{2+}$ and $\mathrm{Mg}^{2+}$ in the water of Babar Dam during the period from January 2013 to March 2016 can be due to the contribution of fertilizers that causes the dissolution of carbonates.

\section{Variation of the chemistry of dam water}

The linear trend was determined using instantaneous concentrations and time Table 1 . The initial and final average values for the period considered allowed us to calculate these variations. It can be seen that for most parameters, the slope differs significantly from zero with the exception of $\mathrm{pH}, \mathrm{O}_{2}$ dis, $\mathrm{T}$ ${ }^{\circ} \mathrm{C}$, $\mathrm{Ca}$ and $\mathrm{NO}_{2}$, where the slope is respectively $-1.24,-7.5,+2.69$, +5 and -4.29 . All other parameters have a positive slope that varies between +10 and $+108 \%$.

The trend line of the temperature is stable with a very low slope of $2.96 \%$. This small increase is probably due to climate change. The slope of the $\mathrm{pH}$ trend line is slightly negative $(-1.24 \%)$. This reflects the presence of low concentrations of organic matter, where the increase in $\mathrm{CO}_{2}$ pressure leads to a decrease in $\mathrm{pH}$ according to the formula proposed by Kempe [34] (5). The salinity of the water represented by the electrical conductivity, it records a negative trend of $(-17.57 \%)$, this is due to the increase of the volume of water in the dam during the period of sampling.

$$
\mathrm{CO}_{2}+\mathrm{H}_{2} \mathrm{O} \leftrightarrow \mathrm{H}_{2} \mathrm{CO}_{3}^{-} \leftrightarrow \mathrm{H}++\mathrm{HCO}_{3}^{-}
$$

The carbonate elements have a slope that differs significantly from zero. They recorded negative trends ranging from $-4.29 \%$ for $\left(\mathrm{Ca}^{2+}\right),-18.95 \%$ for $\left(\mathrm{HCO}_{3}^{-}\right)$and $-44.37 \%$ for $\left(\mathrm{Mg}^{2+}\right)$. These tendencies are related to the equilibrium state of the various minerals in the water and the increase of the water volume of the dam. These variations in carbonate parameters contributed to the decrease in global salinity (CE) by $-17.57 \%$ and a drop in $\mathrm{pH}$ of $-1.24 \%$ (Figure 3).

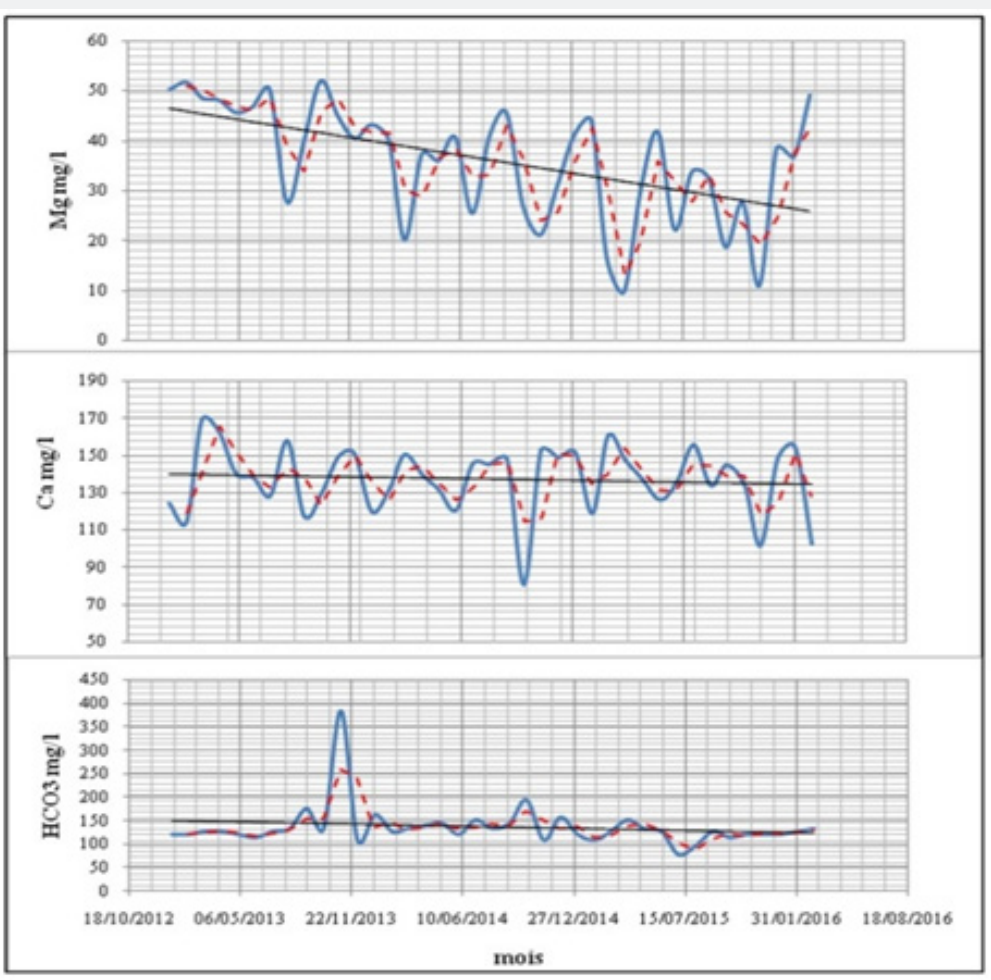

Figure 3: Variation of carbonated elements in water during the period January 2013-March 2016. Continuous trait: data, discontinuous line: moving average, line: linear trend.

For most salt elements, trend analysis showed a negative slope ranging from $-34.21 \%$ for $\left(\mathrm{Cl}^{-}\right),-22.04 \%$ for $\left(\mathrm{Na}^{+}\right),-13.10 \%$ for $\left(\mathrm{SO}_{4}^{-2}\right)$. On the other hand, a positive trend was recorded for $\mathrm{K}^{+}(+41.56 \%)$ (Figure 4). These trends are related to the increase in the water volume of the dam which allows a dilution of the different chemical elements. On the other hand, the use of potash fertilizers and the discharge of wastewater from the villages directly into the main watercourse, lead to the increase of $\mathrm{K}^{+}$. 


\section{Civil Engineering Research Journal}

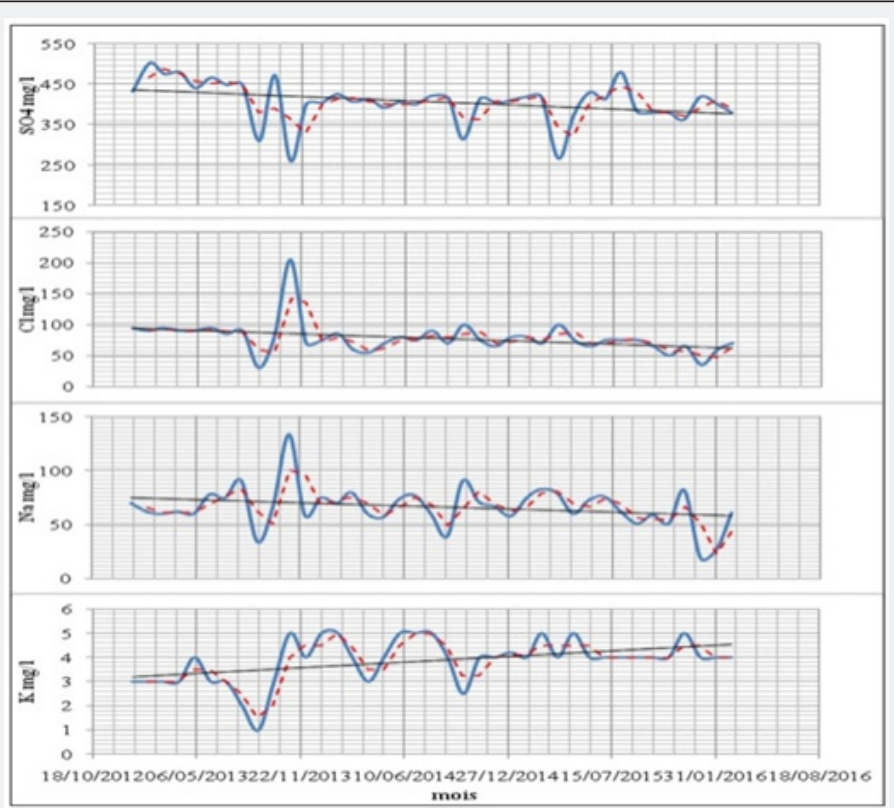

Figure 4: Variation of salt elements in water during the period of January 2013-March 2016. Continuous trait: data, discontinuous line: moving average, line: linear trend.

\section{Legend}

$y=a t+b:$ Relation: Concentration/time.

$\mathrm{T}(\%)$ : Trend (\%).

Min.: Minimum.

Max.: Maximum.

Avg.: Average.

$\sigma:$ Standard deviation

NA: Algerian standards.

$\mathrm{CV}$ : coefficient of variation.
R: Correlation (Vr-Parameters).

The salinity of water is represented by the electrical conductivity and the variation of this parameter makes it possible to follow the evolution of the global salinity and the chemistry of the water. In the long term, there was a decrease of $-17.54 \%$, due to the increase in the volume of water in the dam. Salinity can have two origins, either carbonate or salt. To determine this origin, we established the ratio $\mathrm{Ca}^{2+}+\mathrm{Mg}^{2+}+\mathrm{HCO}_{3}-\mathrm{Na}^{+}+\mathrm{Cl}^{+}+$ $\mathrm{SO}_{4}{ }_{4}^{2-}$ vs CE. The ratio $\mathrm{Ca}^{2+}+\mathrm{Mg}^{2+}+\mathrm{HCO}_{3}{ }^{-} / \mathrm{Na}^{+}+\mathrm{Cl}^{-}+\mathrm{SO}_{4}{ }^{2-}<1$. This reflects the influence of salt minerals on salinity (Figure 5). The increase in the content of the salt elements allows the increase of the salinity. This resulted in a negative trend in the $\mathrm{Ca}^{2+}+\mathrm{Mg}^{2+}+$ $\mathrm{HCO}_{3}{ }^{-} / \mathrm{Na}^{+}+\mathrm{Cl}^{-}+\mathrm{SO}_{4}{ }^{2-}$ vs CE relationship.

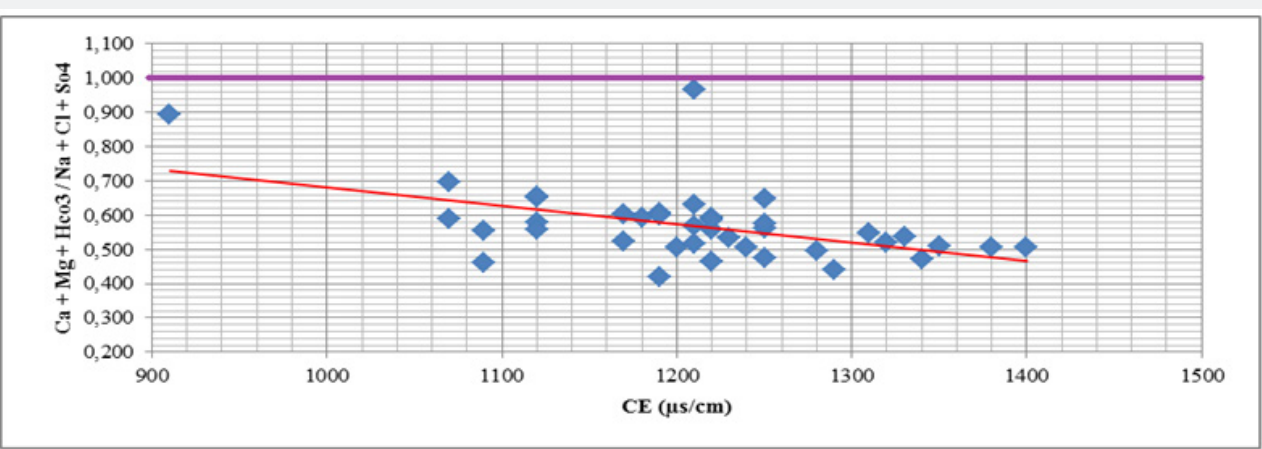

Figure 5: Origin of surface water salinity of the Babar dam.

The electrical conductivity of the different samples shows a good correlation with the elements $\left(\mathrm{Na}, \mathrm{Ca}, \mathrm{Mg}, \mathrm{SO}_{4}, \mathrm{Cl}\right)$ with a correlation coefficient of $(0.34,0.27,0.43,0.68,0.4)$. These strong correlations indicate the direct contribution of these elements in the salinity of the surface waters of the dam. By tale, potassium $(R=-0.1)$ and bicarbonates $(-0.11)$ do not seem to influence too much the salinity of the water. The dissolution of the carbonated and evaporated minerals is done according to the reactions (6 to 11). [35].

$$
\begin{aligned}
& \mathrm{CO}_{2}+\mathrm{H}_{2} \mathrm{O} \leftrightarrow \mathrm{H}_{2} \mathrm{CO}_{3-} \\
& \mathrm{H}_{2} \mathrm{CO}_{3} \leftrightarrow \mathrm{HCO}_{3}^{-}+\mathrm{H}_{3} \mathrm{O}^{+}
\end{aligned}
$$




\section{Civil Engineering Research Journal}

$\mathrm{CaCO}_{3}+\mathrm{H}_{2} \mathrm{O}+\mathrm{CO}_{2} \leftrightarrow \mathrm{Ca}^{2+}+2 \mathrm{HCO}_{3}^{-}$

Dolomite: $\mathrm{CaMg}\left(\mathrm{CO}_{3}\right)_{2}+2 \mathrm{CO}_{2}(\mathrm{~g})+2 \mathrm{H}_{2} \mathrm{O}<==>\mathrm{Ca}^{2+}+\mathrm{Mg}^{2+}+$ $4 \mathrm{HCO}_{3}$

Gypsum: $\mathrm{CaSO}_{4}+2 \mathrm{H}_{2} \mathrm{O}<==>\mathrm{Ca}^{2+}+\mathrm{SO}_{4}{ }^{2-}+2 \mathrm{H}_{2} \mathrm{O}$

Halite: $\mathrm{NaCl}<===>\mathrm{Na}^{+}+\mathrm{Cl}^{-}$

\section{Impact of organic pollution}

$\mathrm{pH}$ and dissolved oxygen showed a respective negative trend of -1.24 and $-7.5 \%$ Table 1 . The oxidation of the organic material according to the reaction 12 or the increase of the $\mathrm{CO}_{2}$ pressure lead to a decrease in the $\mathrm{pH}$ according to the formula 13 proposed by KEMPE [34].

$$
\begin{aligned}
& \mathrm{CH}_{2} \mathrm{O}+\mathrm{O}_{2} \leftrightarrow \mathrm{CO}_{2}+\mathrm{H}_{2} \mathrm{O} \\
& \mathrm{CO}_{2}+\mathrm{H}_{2} \mathrm{O} \leftrightarrow \mathrm{H}_{2} \mathrm{CO}_{3}^{-} \leftrightarrow \mathrm{H}^{+}+\mathrm{HCO}_{3}^{-}
\end{aligned}
$$

The negative trend of MO $(-24.52 \%)$ is in line with the trend of the MES $(-42.81 \%), \operatorname{DCO}(-11.08 \%)$ and that of the $\mathrm{DBO}_{5}$ $(-38.33 \%)$. This can be explained by the installation of conditions of degradation of organic matter by microorganisms. This degradation was accompanied by a decrease in dissolved oxygen of $(-7.5 \%)$ and a decrease in $\mathrm{pH}(-1.24 \%)$.

Data analysis shows a positive trend for $\mathrm{NO}_{3}{ }^{-}(35.62 \%), \mathrm{NO}_{2}{ }^{-}$ (5). This is mainly due to the development of intensive agricultural production upstream of the dam and urban discharges [36] into the main stream without any prior treatment. Moreover, this gradual increase in $\mathrm{NO}_{3}^{-}$concentration corresponds to the yield of nitrification, in the presence of oxygen aerobically according to the reactions (14) and (15) [37]. This oxidation allowed a decrease of oxygen of $-7.5 \%$.

$$
\begin{aligned}
& \mathrm{NH}_{4}^{+}+3 / 2 \mathrm{O}_{2}+\mathrm{H}_{2} \mathrm{O} \rightarrow \mathrm{NO}_{2}+2 \mathrm{H}_{3} \mathrm{O}^{+} \\
& \mathrm{NO}_{2}{ }^{-}+1 / 2 \mathrm{O}_{2} \rightarrow \mathrm{NO}_{3}^{-}
\end{aligned}
$$

This positive trend is also related to the use of fertilizers on these agricultural soils, this has been evidenced throughout the world by El Achheb [38], Fischer et al. [39], Grenz et al. [40], Travi et al. [41] and in Algeria by several authors like Boudoukha et al. [29]. Indeed the form of nutrient is very toxic for both man and the aquatic world. This explains why the release of nitrogen in this form poses a potential risk to the environment [42].

The phosphorus trend $(-80 \%)$ does not follow the same trend as nitrates and nitrites, this situation can be explained by the immobility of this element on the one hand, and on the other hand, the elimination of phosphorus by mechanical erosion processes from adsorption of the latter by soil colloids $[33,43]$. It can also concern the regulation of phosphorus concentrations in Wadi waters by several biogeochemical processes such as apatite precipitation $\left[\left(\mathrm{PO}_{4}\right)_{3}(\mathrm{~F}, \mathrm{Cl}, \mathrm{OH}) \mathrm{Ca}_{5}\right][44]$ and consumption by aquatic plants [45-48].

\section{Influence of water volume}

Looking at the trend line shows a positive trend (+3.41\%), as the inputs represented by precipitation are greater than the outputs represented by evaporation. The analysis of the evolution of the volume of water according to the various hydrochemical parameters shows a very significant linear correlation between the volume of water and the parameters with a stronger negative bond ( -0.35 to -0.81 ) for (MES , $\mathrm{EC}, \mathrm{DBO}_{5}, \mathrm{SO}_{4}, \mathrm{DCO}, \mathrm{Mg}$ ), a weak negative bond (-0.001 to -0.21) for ( $\mathrm{pH}, \mathrm{MO}, \mathrm{NO}_{3}, \mathrm{Na}, \mathrm{Ca}, \mathrm{NH}_{4}, \mathrm{PO}_{4}$, $\mathrm{Cl})$ and for the rest positive bonds were recorded such as $\mathrm{HCO}_{3}$ (0.129), $\mathrm{NO}_{2}(0.22), \mathrm{K}(0.51), \mathrm{O}_{2}(0.06)$. On this basis, it is noted that most of the bonds are significant at the threshold of $10 \%$, except $\left(\mathrm{pH}, \mathrm{NO}_{3}, \mathrm{Na}, \mathrm{O}_{2}\right.$ ) which highlights either a phenomenon of dilution or concentration depending on the case.

\section{Conclusion}

The temporal evolution of physicochemical parameters was monitored during the 39-month period. The results show that most of the parameters follow negative trends, with the exception of $\mathrm{K}(41.56 \%), \mathrm{NO}_{2}(5 \%)$ and $\mathrm{NO}_{3}(35.62 \%)$. The use of potash fertilizers and the dumping of village waste directly into the dam basin without any prior treatment leads to an increase in $\mathrm{K}$. The increase in $\mathrm{NO}_{3}$ is mainly due to fertilizer input and ammonium nitrification (-61\%), which was accompanied by a drop in dissolved oxygen levels (-7.5\%). The decrease of the orthophosphate content $(-80 \%)$ is due to its low mobility on the one hand, and the elimination of phosphorus on the other hand by the mechanical erosion processes from adsorption of the latter by the colloids of the soil.

\section{References}

1. Zarei H, Bilondi MP (2013) Factor analysis of chemical composition in the Karoon River basin, southwest of Iran. Appl Water Sci 3(4): 753761.

2. Sheela AM, Letha J, Joseph S, Chacko M, Sanalkumar SP, et al. (2012) Water quality assessment of a tropical coastal lake system using multivariate cluster, principal component and factor analysis. Lakes \& Reservoirs: Research and Management 17(2): 143-159.

3. Guler C, Thyne GD, McCray JE, Turner AK (2002) Evaluation of graphical and multivariate statistical methods for classification of water chemistry data. J Hydrogeol 10(4): 455-474.

4. Razmkhah H, Abrishamchi A, Torkian A (2010) Evaluation of spatial and temporal variation in water quality by pattern recognition techniques: a case study on Jajrood River (Tehran, Iran). I Environ Manage 91(4): 852-860.

5. Hamzaoui-Azaza F, Ketata M, Bouhlila R, Gueddari M, Riberio L (2011) Hydrogeo-chemical characteristics and assessment of drinking water quality in Zeuss-Koutine aquifer, southeastern Tunisia. Environmental Monitoring and Assessment 174: 283-298.

6. Etchanchu D, Probst JL (1988) Evolution of the chemical composition of the Garonne River water during the period 1971-1984. Journal des Sciences Hydrologiques, 8 eme édition: Dunod, Paris 33(3): 243-256.

7. Ouddane B, Fischer JC, Wartel M (1992) Evaluation statistique de la répartition des métaux en trace $\mathrm{Cd}, \mathrm{Pb}, \mathrm{Cu}, \mathrm{Zn}$ et $\mathrm{Mn}$ dans la Seine et son estuaire. Oceanologica 15(4): 347-357.

8. Tiwary RK, Dhar BB (1994) Effect of coal mining and coal based industrial activities on water salinity of the river Domodar with specific reference to heavy metal. International Journal of Surface Mining, reclamation and Environment 8(3): 111-115.

9. Teixeira EC, Sanchez JCD, Migliavacca D, Binotto RB, Fachel JMC (1999) Environmental assessment: Study of metals fluvial sediments in sites 


\section{Civil Engineering Research Journal}

impacted bay coal processing and steel industry activities. Fuel 79 1539-1546.

10. Jingsheng C, Xvemin G, Dawei H, Xinghui X (2000) Nitrogen contamination in the Yangtze river system, China. Journal of Hazardous Materials, A73, pp. 107-113.

11. Walling DE, Russell MA, Webb BW (2001) Controls on the nutriment content of suspented sediment transported by British rivers. The Science of the Total Environment 266(1-3): 113-123.

12. Lake IR, Lovett AA, Hiscock KM, Betson M, Foley A, et al. (2003) Evaluating factors influencing groundwater vulnerability to nitrate pollution: developing the potential of GIS. Journal Environmental Management 68(3): 315-328.

13. Widory D, Kloppmann W, Chery L, Bonnin J, Rochdi H, et al. (2004) Nitrate in groundwater: an isotopic multi-tracer approach. Journal Contamination Hydrology 72(1-4): 165-188.

14. Ghachtoul YEl, AllaouiMhamdi M, Gabi H (2005) Eutrophisation des eaux des retenues des barrages Smir et Sahla (Maroc) : causes conséquences et consignes de gestion. Rev Sci Eau 18/Spécial 18: 7589.

15. Liu A, Ming J, Ankumah RO (2005) Nitrate contamination in private wells in rural Alabama, United States. Sciences Total Environmenta 346(1-3): 112-120.

16. Rao N (2006) Nitrate pollution and its distribution in the groundwater of Srikakulam district, Andhra Pradesh, India. Environmental Geology 51(4): 631-645

17. Guillaud JF, Bouriel L (2007) Relation concentration-débit et évolution temporelle du nitrate dans 25 rivières de la région Bretagne (France) Rev Sci Eau 20(2): 213-226.

18. Bouguerne A (2001) Etude comparative par analyse hydrologique et hydrochimique des eaux de surface des bassins versants de oued Bousselem et Oued Rhumel. Mémoire de Magister Dép Hydrau Univ Batna, pp. 252.

19. Belhadj MZ (2007) Etude de la pollution des eaux de surface du barrage de Zit El Anba. Région Est de Skikda. NE algérien. Mémoire de Magister Dép Hydrau Univ Batna, pp. 225.

20. GuerRaiche Z, Boudoukha A, Mekaoussi H (2007) Qualité minérale des eaux de surface en zone aride: Cas de Oued El Hai, Barrage : Fontaine des gazelles. Région de Biskra, SE algérien. Physical and Chemica News 38: 112-121.

21. Kemmoukh S (2008) Dégradation de la qualité des eaux du barrage de Zerdazas suite à une pollution naturelle. W de Skikda. Est algérien. Mémoire de Magister Dép. Hydrau. Univ Batna pp. 215.

22. Boudoukha A, Bouguerne A (2010) Les métaux lourds dans les eaux de surface de Oued Bousselem; discussion des données analytiques. Geomaghreb 6: 97-104

23. Tiri A (2010) Pollution urbaine et industrielle des eaux de surface Cas du barrage de Koudi at Medaouar. Batna. Est Algérein. Thèse de Doctorat. Dép Hydrau Univ Batna pp. 265.

24. Tiri A, Belkhiri L, Boudoukha A, Lahbari L (2011) Characterization and evaluation of the factors affecting the geomistry of surface water of Koudiat Medouar basin, Algéria. African Journal of environmental Science and Technology 5(5): 355-362.

25. Boudoukha A, Belhadj MZ, Benkadja R (2012) Impact d'une pollution anthropique et d'une contamination naturelle sur la qualité des eaux du barrage de Zit Emba. Est algérien. La Houille Blanche 4: 34-41.

26. Tiri A., Lahbari N, Boudoukha A (2014) Multivariate Statistical Analysis and Geochemical Modeling to Characterize the Surface Water of Oued Chemora Basin, Algeria. Natural Resources Research p. 1-13.
27. Guerraiche Z, Boudoukha A, RachidBenkadja (2016) Variation of the chemical composition of Grouz dam waters, Eastern Algeria. Desalination and Water Treatment 57(2016): 4878-4887.

28. Belhadj MZ, Boudoukha A, Mezedjri L (2011) Qualité Des Eaux De Surface et Leur Impact Sur L'environnement Dans la Wilaya de Skikda (Nord-est de l'Algérie). (Contamination Naturelle Par le Mercure). European Journal of Scientific Research 56(2): 204-211.

29. Boudoukha A, Boulaarak M (2013) Pollution des eaux du barrage de Hammam Grouz par les nutriments (Est algérien). Bull Serv Géol Nat 24(2): 139-149.

30. Gaagai A, Boudoukha A, Boumezbeur A, Benaabidate L (2017) Hydrochemical characterization of surface water in the Babar watershed (Algeria) using environmetric techniques and time series analysis. International Journal of River Basin Management 15(3): 361372.

31. Faurie G (1977) Etude in vitro du rôle de la nitrification sur la lixiviation du calcium dans les sols calcaires. Science du Sol 4: 204-218.

32. Durand R (1978) La pédogénèse en pays de craie dans le Nord-Est de la France. Thèse de Doctorat. Univ Louis Pasteur Strasbourg.

33. Boudoukha A, Bouguerne A, Mebarkia A (2014) Impact du changement climatique et de l'activité anthropique sur la qualité des eaux du barrage Ain Zada. Algérie. International journal for environnent \& global climat change 2(3): 74- 85

34. Kempe S (1982) Long-term records of the C07 pressure fluctuations in fresh water. Miditerreen Geololy Palaontology Institut 52: 91-332.

35. Appelo CAJ, Postma D (1993) Geochemistry, groundwater and pollution. Journal of Hydrology 155 (1-2): 295-296.

36. Queneau P, Hubert J (2009) Place des eaux minérales dans l'alimentation. Rapport de l'académie national de médecine. Société française de l'hydrologie et climatologie médicale. France. pp 175-220.

37. Martin G (1979) Le problème de l'azote dans les eaux. Technique et Documentation. Paris éd, pp. 279.

38. El achheb A (2002) Essai de bilan des flux azotés percolant vers les eaux souterraines sous climat semi-aride (cas des périmètres irrigués des Doukkala, Maroc). Revue française de Géotechnique 101: 105-111.

39. Fischer JC, Boughriet A, Ouddane B, Bodineau L (2000) Comportement des polluants métalliques et de la matière organique en Manche. Revue Océans 23 (1): 89-111.

40. Grenz C, Alliot Z, Baudinet D, Helis L, Masse H (1992) Influence des opérations de dévasage sur les flux de nutriments à l'interface eau sédiment (bassin de Thau, France). Revue vie milieu 42(2): 157-164.

41. Travi Y, Mudry J (1997) Méthode pour l'évaluation du risque nitrate dans les aquifères de socle de la zone sahélienne d'Afrique de l'Ouest. Revue hydrogéologie 1:13-21.

42. Metahri MS (2012) élimination de la pollution azotée phosphatée des eaux usées traitées, par des procédés mixtes, cas de la STEP Est de la ville de TiziOuezou. Thèse de Doctorat, univTizi Ouezou, pp. 172.

43. Bouguerne A (2017) Relation pluie- débit et concentration des polluants dans les Oueds. Boussalem et Rhumel. Est Algérien. Thèse Doctorat En Sciences. Université Batna 2: 249.

44. Golterman HL, Meyer ML (1985) The geochemistry of two hard water rivers, the Rhine and the Rhone: Part 4: The determination of the solubility product of hydroxy-apatite. Hydrobiologia 126: 25-29.

45. Johnson AH, Bouldin DR, Goyette EA, Hedges AM (1976) Phosphorus loss by stream transport from a rural watershed: quantities, processes and sources. Environmental Journal Quality 5(2): 148-157.

46. Probst JL (1985) Nitrogen and phosphorus exportation in the Garonne basin (France). Hydrology 76(3-4): 281-305. 


\section{Civil Engineering Research Journal}

47. Kattan Z, Salleron JL, Probst JL (1987) Bilans et dynamique de transfert de l'azote et du phosphore sur le bassin de la Moselle (Nord-Est de la France), Sciences de l'Eau 5(4): 437-461.

48. Pilleboue E, Dorioz JM (1986) Mass balance and transfer mechanisms of phosphorus in a rural watershed of lac Léman, France. In: Sediment and Water Interaction (Proc. 3rd Sediment, Freshwater Symp.) (ed. by P. G. Sly), pp. 91-102.
49. Bouguerne A, Boudoukha A, Tiri A (2010) Evaluation des Eaux de Surface à L'échelle des Bassins Versants Par le Code HBV Light et Risque de Pollution Par les Metaux Lourds: Cas de Deux Bassins Versant de L'est Algerien. Journal International Network Environmental Management Conflicts, Santa Catarina-Brazil 1(1): 120-127.

\section{Your next submission with Juniper Publishers} will reach you the below assets

- Quality Editorial service

- Swift Peer Review

- Reprints availability

- E-prints Service

- Manuscript Podcast for convenient understanding

- Global attainment for your research

- Manuscript accessibility in different formats

( Pdf, E-pub, Full Text, Audio)

- Unceasing customer service

Track the below URL for one-step submission https://juniperpublishers.com/online-submission.php 